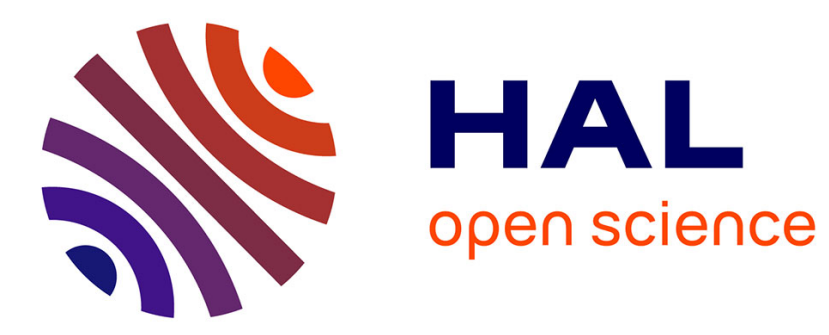

\title{
Dynamic of boron in forest ecosystems traced by its isotopes: A modeling approach
}

Benjamin Chetelat, Jerome Gaillardet, Jiubin Chen

\section{To cite this version:}

Benjamin Chetelat, Jerome Gaillardet, Jiubin Chen. Dynamic of boron in forest ecosystems traced by its isotopes: A modeling approach. 10.1016/j.chemgeo.2020.119994 . insu-03039839

Chemical Geology, 2020, pp.119994.

HAL Id: insu-03039839

https://hal-insu.archives-ouvertes.fr/insu-03039839

Submitted on 4 Dec 2020

HAL is a multi-disciplinary open access archive for the deposit and dissemination of scientific research documents, whether they are published or not. The documents may come from teaching and research institutions in France or abroad, or from public or private research centers.
L'archive ouverte pluridisciplinaire HAL, est destinée au dépôt et à la diffusion de documents scientifiques de niveau recherche, publiés ou non, émanant des établissements d'enseignement et de recherche français ou étrangers, des laboratoires publics ou privés. 


\section{Journal Pre-proof}

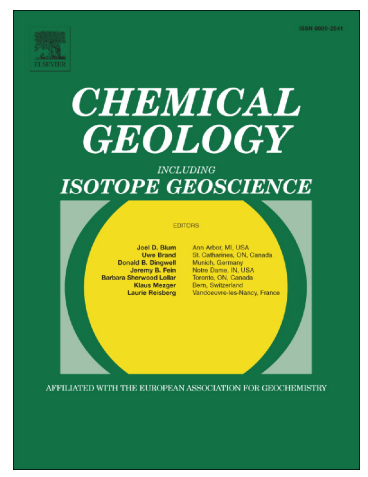

Benjamin Chetelat, Jérôme Gaillardet, JiuBin Chen

PII: $\quad$ S0009-2541(20)30533-7

DOI: $\quad$ https://doi.org/10.1016/j.chemgeo.2020.119994

Reference: $\quad$ CHEMGE 119994

To appear in: $\quad$ Chemical Geology

Received date: $\quad 25$ August 2020

Revised date: $\quad 17$ November 2020

Accepted date: $\quad 20$ November 2020

Please cite this article as: B. Chetelat, J. Gaillardet and J. Chen, Dynamic of boron in forest ecosystems traced by its isotopes: A modeling approach, Chemical Geology (2020), https://doi.org/10.1016/j.chemgeo.2020.119994

This is a PDF file of an article that has undergone enhancements after acceptance, such as the addition of a cover page and metadata, and formatting for readability, but it is not yet the definitive version of record. This version will undergo additional copyediting, typesetting and review before it is published in its final form, but we are providing this version to give early visibility of the article. Please note that, during the production process, errors may be discovered which could affect the content, and all legal disclaimers that apply to the journal pertain.

(C) 2020 Published by Elsevier. 


\title{
Dynamic of boron in forest ecosystems traced by its isotopes: A modeling approach
}

\author{
Benjamin Chetelat $^{1 *}$, Jérôme Gaillardet ${ }^{2}$ and JiuBin Chen $^{1}$
}

1 School of Earth System Science, Institute of Surface Earth System Science (ISESS), Tianjin University, 92 Weijin Road, 300072 Tianjin, China

2 Equipe de Géochimie des Enveloppes Externes, IPGP, 1 rue Jussieu, 750 - Paris, France and Institut Universitaire de France

*Corresponding author: benjam@tju.edu.cn; b.chetela+^yahoo.com; Tel: +86 18202634315

Keywords: Boron isotopes, nutrients, forest ecosvsi $\mathrm{ms}$, Inodeling, plant demand

\section{Highlights:}

1. We developed a model to assess thn $d_{\mathrm{l}} n=$ mic of boron and its isotopes in forest ecosystems

2. Responses of B dynamic to 1 tturai and anthropogenic forcings are reflected in the B isotopic compositions of the different ec.sv'stem's pools

3. B isotopes reveal a po 'nual tracer of nutrient cycling and a promising proxy for tracing the global functioning of terrestrial biosphere 


\section{Abstract}

Understanding the factors that control the cycling of nutrients in terrestrial ecosystems is of fundamental importance given its role for example in nutrient availability to sustain forest productivity, and ultimately in soil carbon storage.

In this paper, we developed a model to assess the dynamic of bor $~ ?$ in forest ecosystems and to appraise how the impacts on boron cycling by internal or external fact ,rs should be reflected in the changes of its isotopic compositions across an ecosystem. Der pitc ¿ile scarcity of data, we tested this model on two case studies and were able to reproduce thc dist ibution of boron isotopes between the different pools of these two contrasted ecosystems. " $\mathrm{nf}$ rnodel shows a time dependency of the boron isotopic composition of the different biotic na abs tic compartments of the ecosystem. When the forest grows, a transient enrichment in the heavy isotope up to $20 \%$ o relative to the values at steadystate is observed in the biomass and $h f=-$ il solutions. The magnitude of this enrichment, and the return time to steady state, are r. $_{1}$-itive to B supply and plant demand for boron. Responses of B dynamic to natural or anthronoge ic disturbances is well reflected in the variations of the B isotopic compositions of the dif:'re 't pr ols that make B isotopes a good potential tracer of nutrient cycling and by extension make boro. . sotopes a promising proxy for tracing the global functioning of terrestrial biosphere at present and in the past. 


\section{Introduction}

Boron is an essential micronutrient for the growth of higher plants. A large fraction of boron in plants is located in cell walls where it ensures the formation and stabilization of its structure via the formation of cross-linked pectic network (O’Neill et al., 2001)

Beside ensuring cell wall structure and possibly influencing its biochemical properties (Fleisher et al., 1999), boron is involved in various physiological processes in vascular , lants. It has been proposed to play a role in plant nitrogen assimilation (Bolanos et al., 2004), the 'eve opment of root nodules in Nfixing plant (Yamagishi and Yamamoto, 1994), metabolism of n neı._.'.c compounds (Pfeffer et al., 1998) and to be involved in the expression levels of a number of g. nes ,Camacho-Cristóbal et al., 2008). Apart from these physiological roles, boron may influ en _e litter composition and decomposition (Lehto et al., 2010) thus affecting nutrients turnover - nd Iltı.'ately carbon cycle in forest ecosystems.

Although the fundamental role of boror for the growth of plants has been recognized since 1920's (Warington,1923), its biogeochemical yrit in ecosystem has retained little attention. It has been proposed that boron along with $\mathrm{K} \cdot \mathrm{V}_{\mathrm{a}}{ }^{-}$the most important nutrient influencing tree species distribution in tropical regions (John et al. 20 $\urcorner$. Steidinger et al., 2015) although this conclusion has been recently refuted by Turner et al. '?0. 7).

Studies on the status of ' $\mathrm{s}$ ron and importance of vegetation cycling in forest ecosystem have also leaded to contrasting results.

For instance, Turner et al. (2017) estimated that the flux of boron supplied by rainfall to tropical forest ecosystem in Panama was equivalent to the annual amount of B returning to the forest floor in litter fall, suggesting that B was not a limiting nutrient. They concluded that the plant requirement for B was considerably less than for phosphorus for example 
By contrast, Gaillardet and Lemarchand (2018) reported fluxes for vegetation cycling 5 to 10 times greater than the total B supply to the ecosystems by atmospheric depositions and chemical weathering for two ecosystems developed under tropical and temperate climates. These larges biological fluxes are in line with the estimation at the global scale by Park and Schlesinger (2002) who estimated that the internal recycling of boron by vegetation on land was one order of magnitude larger than the inputs of boron and its export by large rivers.

As for other nutrients like $\mathrm{K}$ or $\mathrm{Si}$, the distribution and seasonal variatior of $\mathrm{B}$ between plant tissues, soil organic matter, soil solutions and surface water are probably influ nce $d$ by biotic processes but the connection between plant demand and boron cycling in ec =ystems needs to be elucidated. Contribution from external inputs by atmospheric depositı ns, ' Jss of soil organic matter by erosion or feedback between supply by chemical weatherin -nd plant demand along with responses to

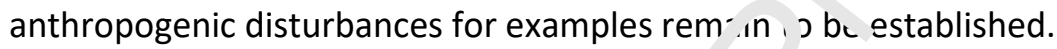

In this regard, mass dependent fractic ation c: stable isotopes can be used effectively to trace processes which transfer matter to or $\mathrm{O}^{\prime} \mathrm{t}$-nd from one compartment to another in an ecosystem (Bouchez et al., 2013). For instance s. ?ble isotopes of Ca and Si have been successfully used to trace the cycling of these elements in foreste ${ }^{\prime}$ ecosystems (Holmden and Belanger, 2010, Riotte et al., 2018).

With the exception of $\cdot$ are ma smatic environments, boron is always bound with oxygen and can be three or four coordinate. 'ror example, in aqueous solution boron forms an acid base couple $(\mathrm{pKa}=$ 9.24 at $25^{\circ} \mathrm{C}$, Baes and Mesmer, 1976) where boric acid, $\mathrm{B}(\mathrm{OH})_{3}$, is trigonal and borate ion, $\mathrm{B}(\mathrm{OH})_{4}{ }^{-}$, is tetrahedral. Boron has two stable isotopes, ${ }^{10} \mathrm{~B}$ and ${ }^{11} \mathrm{~B}$ and the higher bond strength of the trigonal coordination, explains its enrichment in ${ }^{11} \mathrm{~B}$ relative to the tetrahedrally coordinated boron. For instance, boric acid is enriched in ${ }^{11} \mathrm{~B}$ by about $27 \%$ compared with borate ion (Klochko et al., 2006). Thus, changes of coordination between different phases induce large isotopic fractionations for example during incongruent dissolution of minerals, adsorption onto mineral or organic surfaces. Moreover, 
boron isotopes are potentially fractionated during its uptake by roots (Marentes et al., 1997; Cividini et al., 2010; Geilert et al., 2019) and strong evidences exist that intra-plant isotopic fractionations exist (Geilert et al., 2015; Gaillardet and Lemarchand, 2018). At the scale of the ecosystem, the B isotopic compositions, expressed in the classical $\delta$ notation, of different compartments cover a range up to $80 \%$ o (Cividini et al., 2010; Gaillardet and Lemarchand, 2018) and vegetation (leaves) and leaf exudates appear to be enriched in the heavy isotope relative to atmospheric inputs and soil.

This paper is an attempt, through a modeling approach, to predict the isotopic signatures of different pools during the development of a forested ecosystem and how the impacts on boron cycling by external factors are reflected in the changes of its isoton c c.....positions across the ecosystem. Especially we examined the distribution of B isotopic con, 'osi ions of soil solutions and by extension those of streams or rivers, as a signature of biotic $1 e^{r} \cdot 1$ nd in terrestrial ecosystems under different boron supply rates and anthropogenic forcin's. he osults of the model show the strong promise of boron isotopes in ecosystems as a proxy $f \sim r$ terres $r$ ial biosphere functioning.

\section{Methods}

\subsection{General description of the mo, 'ol}

A synthetic view of th $m$, del with the different pools and fluxes is illustrated Figure 1. A list and a description of the pools, " from a bare ground and the forest develops through time till the living biomass reaches an equilibrium for which the biomass remains constant. We do not explicetly model the forest development and the evolution of the carbon stocks but we model the evolution of the different boron stocks and their isotopic compositions till the system reaches a steady-state. 
Figure 1: Schematic description of the model with the different pools and fluxes considered. A list and a description of the pools, fluxes, and parameters are given Tables SI_1 and SI_2

The soil compartment is divided into three soil layers of different sizes, two being located in the root zone and one below the root zone. The upper soil layer, in the following the soil organic layer (SOL), which includes the forest floor and whose thickness increases with the development of the vegetation (Supporting information SI_1), only receives external inputs from … a a mosphere $\left(F_{a t m}\right)$. This layer exchanges dissolved boron with the lower soil mineral layer (SN '-) within the root zone via the downward percolation of water. Boron is supplied to the soi' .. in ' ral layer by chemical weathering (CW) and exported out of the root zone to a mineral layer ( $\mathrm{ML}^{\prime}$ by r .rcolation. This layer is also supplied in boron by chemical weathering at the same rate, $\mathrm{Cl}^{\prime \prime}$, a a $_{\text {- }}$ ile SML. Dissolved boron is leached out of this layer as drainage.

Vegetation takes up boron from the two ıph $r$ layers and we assumed that the uptake rate of boron by the vegetation is partly driven by the w.t. . ranspiration rate (passive uptake) which is a function of soil moisture (Porporato et al., 200s, Buendia et al., 2010) and depends on climate and vegetation characteristics (Porporato $\mathrm{e}^{+} \sim^{\prime} . \angle こ J 3$; Schlesinger and Jasechko, 2014).

To take into account the ru $t$ distribution with depth (Jackson et al., 1996), we assumed that $50 \%$ of the roots are located in the upper soil layer.

\subsection{Boron supply rates by atmospheric depositions and chemical weathering}

In the model, inputs of boron by atmospheric depositions and chemical weathering are taken as variables. Especially, dissolution of primary minerals and precipitation of secondary minerals like clays or oxides oxides (incongruent dissolution) are not explicitly described or modelized. Hence, the input of B by chemical weathering is a net flux. As a consequence, the fractionation of $B$ isotopes during the coprecipitation of boron from the soil solution with secondary minerals (Gaillardet and Lemarchand, 2018 
and references therein) is not modelized either as we consider here that this process occurs over timescales greater than the timescale of ecosystem development. Thus, the $\delta^{11} \mathrm{~B}$ value associated to the chemical weathering flux is also a variable which implicitly takes into account the B isotopes fractionation during the incongruent dissolution of minerals in the soil.

\subsection{Passive vs active boron uptake by the vegetation}

The hypothesis that the uptake of B by plants is passive and only driven by transpiration has been challenged (e.g. Pfeffer et al., 1999). A term describing the active $\iota$. take of boron when the plant demand in boron is not fulfilled by the passive uptake only has there. ㄱe seen introduced in the model. The uptake of boron by plants is regarded as an additive prn ess Letween passive uptake and active uptake (Porporato et al., 2003).

$$
\mathrm{Upt}_{\mathrm{B}}=\mathrm{Upt}_{\mathrm{B}}^{\text {passive }}+\mathrm{Upt}_{\mathrm{B}}^{\mathrm{ac} \mathrm{c}^{\prime} \mathrm{ve}}
$$

Passive uptake is proportional to the water ur akı by plants and the concentration of dissolved boron in the considered soil layer taking into accou. the root distribution with depth.

As we consider two soil layers, the total $\lambda \mathrm{r}$ ca $₫$ of boron, $\mathrm{Upt}_{\mathrm{B}}$ is the sum of the uptake from the two soil layers, SOL and SML, thus the total pa_-ive uptake is given by:

$$
\mathrm{Upt}_{\mathrm{B}}^{\text {passive }}=f(t) \times \eta^{\prime}\left(X \times\left[B_{S O L}\right] \times s_{S O L}+(1-X) \times\left[B_{S M L}\right] \times s_{S M L}\right)
$$

where $s$ is the soil moistu. $\bullet, ;$, the maximum transpiration rate which is assumed to depend on climate and vegetation (Porporato et al., 2003), X the fraction of water absorbed from the soil organic layer, $\left[B_{S O L}\right]$ and $\left[B_{S M L}\right]$ are the concentrations of dissolved boron in the soil organic layer and the soil mineral layer, respectively. The function $\mathrm{f}(\mathrm{t})$ describes the production of biomass with time according to:

$$
f(t)=\left(1-e^{-t / T \max }\right)^{n}
$$

where $t$ is the time, and in the simulations $n$ was chosen equal to 0.952 and $T_{\max }$ to 15 insuring that the biomass production will reach a constant value after less than 100 years. 
We used in the case of boron a similar formalism as proposed by Porporato et al. (2003) to simulate the active uptake of soil nitrogen by vegetation.

Importantly, we defined a boron demand term (Dem), as the optimum flux of boron ensuring optimal growth (expressed in $\mathrm{mol} / \mathrm{m}^{2} / \mathrm{yr}$ ), scaled with the function $\mathrm{f}(\mathrm{t})$ (i.e. the boron demand of the vegetation increases with the biomass production). In the case where the passive uptake does not satisfy the plant demand, an active uptake compensates for the deficit.

Active uptake is assumed to obey Michaelis-Menten type kinetics (Star oulis et al., 2001; Silberbush et al., 2005) when the influx of boron is limiting or equal to the differer, e $k$ stween the plant demand and the passive uptake otherwise. Active uptake of B can then be $\lambda_{1}$ fir $\_$- mathematically as:

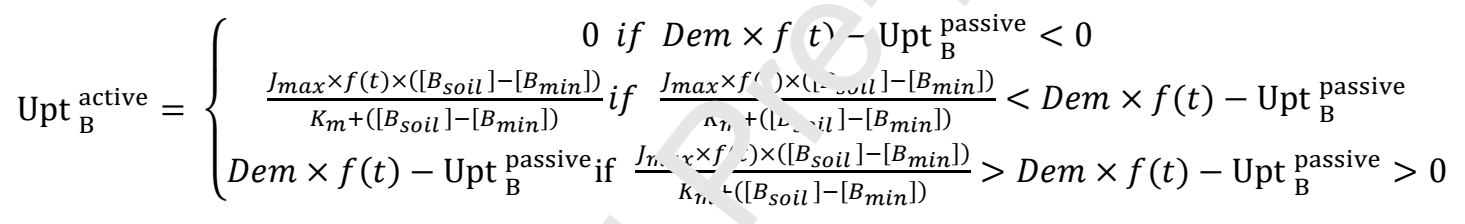

Where $\mathrm{J}_{\max }, \mathrm{K}_{\mathrm{m}}$ and $\left[\mathrm{B}_{\min }\right]$ are maxima، II. ${ }^{\top \mathrm{I}} \mathrm{Ux}$, Michaelis-Menten coefficient and minimal $\mathrm{B}$ concentration (at which $\mathrm{Upt}_{\mathrm{B}}{ }^{\text {active }}=0$ ), respectiv ${ }^{\prime} \mathrm{y} .$. ' ax is a function of root surface area (Dannel et al., 2001; Stangoulis et al., 2001) thus is scaled ',y ${ }^{-1}+$ ), ,.e. $J_{\max }$ increases with the production of biomass and will depend on the root distribution for the ioil layers considered (see Supporting information SI_1 for the estimation of the demand and the different parameters).

\subsection{Allocation of boron to the coarse roots/woody part and leaves}

A fraction of the boron taken by the vegetation is allocated to the roots/wood ( $\left.f_{\text {wood }}\right)$ and the leaves $\left(f_{\text {leaves }}\right)$ whereas the remaining return to the forest floor soil solution as leaf exudates $\left(f_{\text {ex }}\right)$. The fraction of boron exudated $\left(\mathrm{f}_{\mathrm{ex}}\right)$ is fixed at 0.5 , about half of the flux boron returning annually to the forest floor associated to leaf litter fall (Gaillardet and Lemarchand, 2018). The fractions of boron allocated to root/wood $\left(f_{\text {wood }}\right)$ and to the leaves $\left(f_{\text {leaf }}\right)$ are either kept constant through the run to reach a predefined 
ratio between the stock of boron in the root/wood compartment and that in the leaf compartment $\left(\mathrm{B}_{\text {wood }} / \mathrm{Bl}_{\text {eaf }}\right)$ or $\mathrm{f}_{\text {wood }}$ and $\mathrm{f}_{\text {leaf }}$ can be adjusted at each step to keep a nearly constant $\mathrm{B}_{\text {wood }} / \mathrm{Bl}_{\text {eaf }}$ ratio. For instance, the ratio between the living coarse root/wood biomass and the leaf biomass varies from 3 to 8 for birch, pine and spruce stands between 40 years old and 100 years old on drained mire in Finland (Finer, 1989). In addition, Turner et al. (2017) report a ratio of nearly 9 for a lowland tropical forest in Panama of at least 200 years old.

\section{Litter fall and mineralization of soil organic matter}

Boron also returns to the forest floor layer as leaf litter fall and $n$ od debris. The fraction of boron returning each year to the soil as litter is taken proportional to ine _._cks of B in leaves and roots/wood. The rate of boron returning to the floor as leaf litter fall, $k_{\text {leal }}$ was chosen between 0.5 year ${ }^{-1}$ and 1 year ${ }^{-1}$, ensuring that the boron residence time in the leaf $F>0$ : is equal to the leaves turnover i.e. 1 year for

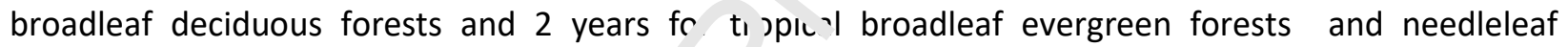
evergreen forests. The boron residence +ime in .he woody parts, equal to the inverse of the rate of boron returning to the floor as wood li $t f_{i}:-11, k_{\text {wood, }}$ is fixed and is assumed to be that of the woody biomass. Residence time of woody bı mass is highly variable from one ecosystem to another (Xue et al., 2017) and can vary from abou 20 , sars to 130 years for tropical forests solely (Galbraith et al., 2013). In the model, we chose th $、$ w odv biomass residence time equal to 100 years.

We distinguish in the mo - , the leaf litter pool from the wood litter pool. The organic boron associated to these two distinct pools has different fates. Whereas, the organic boron associated to the leaf litter pool is rapidly released to the SOL solution via litter decomposition, the wood litter decays more slowly so the associated organic B is characterized by a longer residence time before it is released into the SOL solution. We assumed different decay rates, $\mathrm{k}_{\min }$, for the wood litter and leaf litter of 0.006 year ${ }^{-1}$ for the wood litter and equal to 0.3 year $^{-1}$ for the leaf litter (Pietsch et al., 2014). In the model, litter decay rates vary as a function of the temperature and soil moisture (Lloyd and Taylor, 1994) (Supporting information 
SI_1). In a series of simulations, we examined the effects of soil erosion on the B dynamic. For these simulations, we assumed that the loss of soil organic boron by erosion was proportional to the stocks of B in the leaf and roots/wood litter/humus pools (Supporting information SI_1).

\subsection{Isotopic fractionation during B root uptake, B translocation and organic matter mineralization}

In the model, evolution of the B isotopic compositions of the different pools is controlled by the isotopic fractionation associated to the different processes which control the $B$ " uxes. Only few studies focused on $B$ isotopic fractionation during the transfer of boron from the soil to the plant and during the translocation of boron within the plant. Marentes et al. (1997 S1, . $n$ that for the three plant species they studied, two were enriched in ${ }^{11} B$ relative to the nutr tive solution whereas one shown no enrichment. However, the enrichment in ${ }^{11} B$ measure $d$ ' $e m s$ to be unrealistic which results in isotopic fractionations between the solution and the $F^{\prime} d n_{1}$ in '.'e order of the percent. In contrast, Cividini et al., (2010), concluded on the absence or a sl: tht prelurence for the light isotope (less than $5 \%$ ) during the uptake of B by the vegetation and L spra -hand et al. (2005) shown large isotopic fractionations associated to the complexation of $b_{c}$ - on by organic matter in favor of ${ }^{10} \mathrm{~B}$. More recently, Geilert et al. (2019) suggested the preferential । ' t uptake of ${ }^{11} \mathrm{~B}$ during passive uptake and ${ }^{10} \mathrm{~B}$ during active uptake. In the following, we ass ' $m, f$ th th the boron isotopes absorbed by the roots are potentially fractionated relative to the solution $c^{-1}, \mathrm{f}$ in the case where the uptake of boron by roots is active. We performed different series of simulation with different isotopic fractionation factors i.e. 0.990-0.995 (the light isotope is preferentially absorbed by the roots) and 1 (no isotopic fractionation). In addition, we associated an isotopic fractionation factor of 0.973 to the incorporation of boron into the wood/root (similar to isotopic fractionation factor associated to B complexation by humic acids at $\mathrm{pH}=5-7$, Lemarchand et al. (2005)) and an isotopic fractionation of 0.99 to the allocation of boron to the leaves. The difference between the two isotopic fractionation factors can be explained by the fact that a 
fraction of boron allocated to the leaves is not structurally bound (Camacho-Cristobal et al., 2008; Stangoulis et al., 2010) resulting in an apparent fractionation factor closer to 1 . We modeled the evolution of the isotopic composition between the different organs from the root/wood to the leaves by a Rayleigh distillation as it was observed in the case of Si isotopes for example (Ding et al.,2005). Hence, the isotopic composition of B in solution transported into the plant becomes gradually heavier in the course of the incorporation of boron into plant tissue and progressively increases from the root to the leaves as observed by Geilert et al. (2015). The remaining boron re, rns to the forest floor by leaf exudation without additional isotopic fractionation. To take into co, sidf ration the greater mobility of non-structurally bond boron during organic matter remin raision, we associated an isotopic fractionation factor in favor of the preferential release of $t i$, he vy isotope equal to 1.01 during the leaf litter decay. On the contrary, for the mineralization o th a wood litter, we did not associate any isotopic fractionation.

The isotopic composition of B taken up kv the vesetation is related to that of the soil solution by the relationship

$$
\therefore \cdot n t=\alpha_{u p t} \times R_{\text {sol }}
$$

Where $R_{\text {upt }}, R_{\text {sol }}$ and $\alpha_{\text {upt }}$ are the isc :opic ratios of $B$ taken up by the vegetation, in the soil solution and the isotopic fractionatic. fa tor associated to the B uptake.

Calculation of the isotopic composition of boron taken up vegetation is implemented as follow. Uptake of B by roots occurs in the two soil layers, thus the isotopic composition of boron taken up by vegetation is the average of the isotopic composition of B taken up from the two layers weighted by their uptake fluxes. In addition, we considered that the total uptake is the sum of a passive uptake process which does not induce any isotopic fractionation and an active uptake which favors the uptake of the light isotope. Hence, for each soil layer, the isotopic composition of boron taken up by the roots, is calculated as the average between the passive and active uptakes weighted by their respective contributions. 
The isotopic composition of B accumulated into the root/wood is given by

$$
R_{\text {wood }}=\left[R_{\text {upt }}-R_{\text {upt }} \times\left(1-f_{\text {wood }}\right)^{\alpha_{\text {inc-wood }}}\right] / f_{\text {wood }}
$$

where $R_{\text {wood }}$ is the isotopic composition of $B$ accumulated into the root/wood tissues, $\alpha_{\text {inc-wood }}$ the isotopic fraction factor associated to the incorporation of boron into the wood/roots and $f_{\text {wood }}$ the fraction of boron incorporated into root/wood tissues.

The isotopic composition of B lost by exudation is given by

$$
R_{\text {ex }}=R_{\text {upt }} \times\left(\frac{f_{\text {ex }}}{1-f_{\text {wood }}}\right)^{\alpha_{\text {inc-leaf }}-1} \times\left(1-f_{\text {wood }}\right)^{\alpha_{\text {inn-w.- }}} \times 1
$$

where $R_{e x}$ is the isotopic composition of $B$ returning to the $c n$, hy exudation, $f_{\text {leaf, }}$, the fractionation of boron incorporated into leaf tissue and $\alpha_{\text {inc-leaf }}$ the iso'sp fractionation factor associated to the incorporation of boron into the leaf tissue.

The isotopic composition of B accumulated 1 , to the leaves is given by

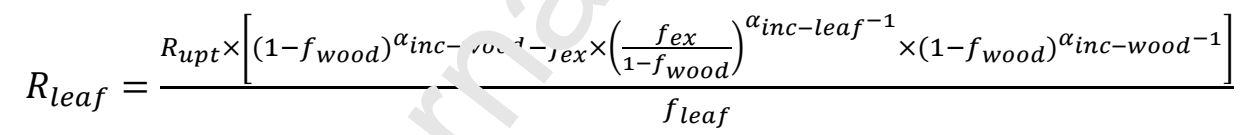

Where $R_{\text {leaf }}$ is the isotopic cor. pos cion of $B$ accumulated into the leaf tissues and $f_{\text {ex }}$ the fraction of boron lost by exudation.

Pools and fluxes along with the different parameters and equations are provided in the Supporting Information SI_1, Tables SI_1 and SI_2.

We tested the model on the two case studies (Cividini et al., 2010; Gaillardet and Lemarchand, 2018) of small watersheds, in which a rather comprehensive distribution of boron and its isotopes between different pools of an ecosystem has been measured. The distribution of the isotopic compositions within the different pools of the ecosystems estimated by the model are in line with the isotopic compositions reported by the authors. A description of the simulations is detailed in the Supporting 
Information SI_2, the values of the different parameters are listed in Tables SI_3 and SI_4 and the results are illustrated in Figures SI_1, SI_2, SI_3 and SI_4.

\section{Results and discussion}

\subsection{Dynamic of boron in forest ecosystems under different supply rates of boron}

We fixed the atmospheric inputs at $0.03 \mathrm{mmol} / \mathrm{m}^{2} / \mathrm{yr}$ and made the 1 , ?uts from chemical weathering vary from 0.1 to 60 times the atmospheric supply resulting in total inpı ts of boron to the ecosystem ranging from about $0.036 \mathrm{mmol} / \mathrm{m}^{2} / \mathrm{yr}$ to $3.63 \mathrm{mmol} / \mathrm{m}^{2} / \mathrm{yr}$. $c_{v} c_{2} \ldots$ parison, the export rates by large rivers of dissolved boron vary from $0.037 \mathrm{mmol} / \mathrm{m}^{2} / \mathrm{yr} \mathrm{fc}_{\mathrm{c}}$ - th. Amazon to $2.22 \mathrm{mmol} / \mathrm{m}^{2} / \mathrm{yr}$ for the Salween (Lemarchand et al., 2002). This formulatir $n$ ff the total B inputs to the ecosystem is in agreement with the conclusions of Lemarchar $d \in$ al. '2002) that globally the export of dissolved boron by rivers are dominated by rock weathering and $w$ ith the general view that atmospheric depositions are the main source of nutrients for lin itr a zcosystems. The boron isotopic compositions of the atmospheric and weathering input a chosen equal to $20 \%$ and $0 \%$, respectively. The relatively high $\delta^{11} \mathrm{~B}$ value chosen for the atmosp eric inputs is compatible with the values measured in continental rainwater (Cividini et al., $2 C^{1} 0$, f oux et al., 2017).

For all the runs, the boroi. - emand of the vegetation and the maximal influx, $\mathrm{J}_{\max }$, were fixed at values of $3 \mathrm{mmol} / \mathrm{m}^{2} / \mathrm{yr}$ and $20 \mathrm{mmol} / \mathrm{m}^{2} / \mathrm{yr}$, respectively, in the range of the values reported for B uptake in forest ecosystem and estimated for $\mathrm{J}_{\max }$ (Supporting Information SI_1). In addition, we performed the same simulations for different values of the isotopic fractionation factor during the active uptake by plants (i.e. $\alpha_{\text {upt }}=1$ and $\alpha_{\text {upt }}=0.99$ ) (Table SI_5). 
3.1.1. Evolution of the boron stocks and isotopic compositions of the different pools during the forest development.

Relative evolutions through time of the stocks of boron in the leaving biomass will depend on how boron taken up by the vegetation is allocated to the coarse root/wood biomass and the leaf biomass. In the case where the fraction of boron allocated to the wood is kept constant to attain a fixed ratio (e.g. 8) between the stocks of boron in the woody biomass and in the leaves when the system has reached a steady state, during the early stages of development, the leaf pool dor inates the stock of boron in the living biomass. Progressively, the stock of boron in the leaving wood L 'om 1 ss increases to reach the final ratio of 8 between the stock of boron in the woody biomass ar $d_{1}$. stock of boron in the leaf biomass (Figure SI_5). In the case where the ratio between the sto - of soron in the wood biomass and the leaf biomass is fixed to a constant value, the fraction of ' 10 ro' allocated to the coarse root/wood biomass progressively decreases to value chosen in the iIrs ' ca_? (Figure SI_5). The time for the system to reach a steady state is a function of the B suppl; by cheı,ical weathering and atmospheric depositions. In the conditions of the simulations, stocks anc $\mathrm{fl} \lambda \lambda$; of boron attain constant values in less than 200 years for systems characterized by relatively $h_{1}$ ¿h supplies of boron whereas for the most limited systems, steady values are not yet reached after 16$\urcorner\urcorner$ years.

Dynamics of the B isote nic -om sositions of the vegetation and the soil solutions under different boron supply rates are illustrate.' :., Figures 2 and 3.

Figure 2: Evolution of the B isotopic composition of the soil solution in 3 different soil layers with the development of a forest for different supply rates of boron (atmospheric inputs, $F_{\text {atm }}$ and chemical weathering, $C W)$ and different $B$ fractionation factors associated $(\varepsilon)$ to the active uptake of boron by roots 
In the case where the active uptake of boron by roots does not fractionate its isotopes, all the simulations show a transient enrichment in ${ }^{11} \mathrm{~B}$ of the soil solutions relative to the inputs. This enrichment is explained by the transient storage of the light isotope in the living biomass and the soil organic pool, especially in the woody biomass characterized by a lower turnover rate than that of the leaf biomass. Because of the storage of the light isotope in the vegetation tissues, exudates are enriched in ${ }^{11} \mathrm{~B}$, partly controlling the isotopic composition of the soil solution especially in the soil organic layer along with the decay of the leaf litter characterized by a rapid decay 1 re. Control of leaf exudates or throughfall on the B isotopic composition of the soil solutions $c a$. bf highlighted by increasing or decreasing the fraction of boron returning to the soil solution $=5$ en. ıate, $f_{e x}$. Higher(lower) values of $f_{e x}$ results in a smaller(larger) fraction of boron stored in the wo dy biomass and in consequence, to $B$ isotopic compositions of exudates less (more) enrich $: d \cdot r^{11} B$ relative to the uptake. Magnitude, up to nearly $20 \%$ for the soil solution in the root $z, n \in$ an' duration, from about 50 years to more than 500 years, of this enrichment appear to derand on ihe B supply to the ecosystem. More exactly, both magnitude and duration depend on the $r_{r} t_{1}$ : between the net storage of boron in the biomass (living and dead) and the total supply (at $n_{\iota}$-oheric deposition and chemical weathering) of boron to the root zone (Figure SI_6). For ecosys ${ }^{+}$ems -haracterized by low supply of boron, the root uptake of boron and the transient storage of ${ }^{10} \mathrm{~B} n$th 2 biomass have a stronger impact on the isotopic composition of the soil solution than for ecosyst - -.s characterized by high supply of boron for which soil solutions are quickly replenished in boron. In the simulations where the ratio between the stock of boron in the woody biomass and the leaf biomass is kept constant during the run, the transient enrichment in ${ }^{11} \mathrm{~B}$ is enhanced compared with the simulations where the fraction of boron allocated to the woody biomass is kept constant (not shown). This result is explained by the larger transient net storage of boron in the woody biomass in the former case (Figure SI_6). For ecosystems characterized by low supply rates of boron, the transient increase of $\delta^{11} \mathrm{~B}$ values of soil solutions within the root zone is enhanced when the 
active uptake of boron by roots favors the uptake of the light isotope because comparatively more ${ }^{10} \mathrm{~B}$ is stored in the woody biomass (Figure 2). However, as the B isotopic composition of the soil solution in SOL is controlled by the overall isotopic composition of the vegetation, it is lower than the B isotopic composition of SML and progressively will becomes enriched in the light isotope relatively to the inputs. The propagation of this transient increase of the soil pore water $\delta^{11} \mathrm{~B}$ value below the root zone is illustrated in Figure 2 which shows that the signal is time delayed and of lower amplitude, buffered to some extent by the B input from chemical weathering. In line with $t_{1}$, conclusions of Gaillardet and Lemarchand (2018), the isotopic composition of soil pore water var. ss $v$ ith depth reflecting the more important contribution of vegetation cycling in the top soil lays - rt:-zive to the deeper layers controlled by weathering reactions.

Figure 3: Evolution of the $B$ isotopic composi..or ; $0_{1}$ the living biomass and the leaf exudate with the development of a forest for different supply ates of boron (atmospheric inputs, $F_{\text {atm }}$ and chemical weathering, CW) and different B fraction ition factors $(\varepsilon)$ associated to the active uptake of boron by roots

Differences in the evolution of $t_{1}$ o is topic compositions of the different vegetation pools (i.e. wood vs leaf) is partly explained by tht different turnover rates. Because of the high turnover rate of the leaf pool, the isotopic compositı in of the leaves responds quickly to the change of the isotopic composition of the soil solution whereas changes of the isotopic composition of the woody biomass are delayed (Figure 3).

3.1.2. Boron distribution and isotopic compositions of the different pools after the ecosystem has reached a steady-state. 
In the conditions of the simulations, after the ecosystem has reached a steady-state, the stock of boron in the living biomass varies from $9.5 \mathrm{mmol} / \mathrm{m}^{2}\left(103 \mathrm{mg} / \mathrm{m}^{2}\right)$ to $12 \mathrm{mmol} / \mathrm{m}^{2}\left(130 \mathrm{mg} / \mathrm{m}^{2}\right)$ when the uptake of boron is active and obeys Michaelis-Menten type kinetics. In these cases, boron is "limiting" as the plant demand is not fulfilled by the root uptake. When the uptake of boron is active and controlled by the demand, (in that case boron is not "limiting") the stock of boron in the living biomass reaches a value of $12.5 \mathrm{mmol} / \mathrm{m}^{2}\left(135 \mathrm{mg} / \mathrm{m}^{2}\right)$. Data on B stock in living biomass for forest ecosystems are scarce but seems to widely vary across different ecosystems. For instance, Fin - (1989) reported stocks of B in above and below ground tree biomass ranging from 15 to nearly $77 \mathrm{r} \cdot \mathrm{g} / \mathrm{r}{ }^{2}$ for tree stands developed on drained mire in Finland whereas Turner et al. (2017) reported t toc:- of B for lowland tropical forests in Panama of nearly $800 \mathrm{mg} / \mathrm{m}^{2}$. Hence the values predicte ' bv the model are in the same order of magnitude with the stocks of boron reported so far in ih'. l iterature.

Figure 4: Relationships at steady state hetweer, the demand normalized to the inputs and (a) the vegetation cycling, (b) the ratio betweer " ? active uptake and the passive uptake of boron by roots, (c) and (d) the enrichment in B of the or s $_{\text {a }}$ ic _ Jil layer and the bottom layer of the root zone. The limit for boron limitation has been fixed a bitra -ily and marks the transition between the two formulations for active $B$ uptake by roots (see toxt to - details)

As expected, at steady-state, the degree of boron cycling by vegetation expressed as the ratio between the total uptake of boron by vegetation and the B hydraulic loss at the base of the SML (equal at steadystate to the total $B$ inputs) increases with the ratio between the total inputs and the plant demand (Figure 4a). In a same way, the ratio between the B active uptake and the B passive uptake by roots increase with the ratio between the total inputs and the plant demand (Figure 4b). Hence, in conditions of low B supply, boron is intensively recycled by the biomass before being exported out of the root zone 
by drainage. This intense recycling of boron by the biomass coincides with a more important contribution of the soil organic layer to the total boron uptake by roots (Figure 4c)

In the case where the uptake by the vegetation is active, the model predicts a progressive boron enrichment in SOL relative to SML along with the increase of boron cycling by vegetation which is in turn controlled by the ratio between the total inputs and the plant demand (Figure 4d). This is in agreement with the general observation that limiting nutrients accumulate in the top soil through vegetation cycling via litter decay and throughfall (Jobbagy and Jackson, 2001, Civic i i et al., 2010).

In the case where the active uptake of boron favors the light isotopt. at ,teady state, evolutions of the difference between the B isotopic compositions of the vegetati, in $n_{R}=$ Jls and the inputs show a decrease with the ratio between the demand and the inputs (Figure $-7 a$ ). Because the B isotopic composition of the SOL is mainly controlled by the inputs from the es, exation, the difference between the B isotopic compositions of the SOL and the inputs follo' $s$ a $\sin$.' $^{\prime}$ ar evolution with the demand normalized to the inputs (Figure SI_7b). The SOL and the vc oetatior, become progressively enriched in ${ }^{10} \mathrm{~B}$ along with the increase of the ratio. In the case where 10 is limiting (i.e. for low supply rates), the B uptake by roots is essentially active (thus resulting : $n$. larger isotopic fractionation) whereas for higher B supply rates, a significant fraction of boron is absc hed passively (resulting in a smaller isotopic fractionation).

In the case where no is . ${ }^{\circ}$ or ic fr ictionation is associated to the active uptake of boron by roots, isotopic composition of the soil $k$ e water within the root zone is homogenized by vegetation cycling and is controlled by the $\delta^{11} B$ value of the inputs.

Leaves are enriched in the heavy isotope by about $20 \%$ relative to the root/wood compartment (Figure SI_7a), in agreement with the observations of Geilert et al., (2015) and Geilert et al. (2019) who measured for various plant species isotopic differences between the upper leaves and the roots between $24 \%$ and $27 \%$. The model predicts an enrichment in ${ }^{11} \mathrm{~B}$ of the leaf exudates relative to the leaves of about 14\%, also in agreement with the observations of Cividini et al. (2010) and Gaillardet and 
Lemarchand (2018).

\subsection{Effects of plant demand on B cycling for B limited ecosystems}

Due to the relative large range of boron uptake rates measured or estimated for forest ecosystems (Finner, 1998; Cividini et al., 2010; Turner et al., 2017; Gaillardet and Lemarchand, 2018), we tested the effects of plant requirement on the boron dynamic in relation with inter species variability and/or in responses to various stresses. For different plant demands, Dem, we $p_{\imath}$ tulated that the maximal influx of boron, $\mathrm{J}_{\max }$, will change accordingly. We carried out a series of sin 'ilat ons for a B limited ecosystem where Dem takes the values of $3 \mathrm{mmol} / \mathrm{m}^{2} / \mathrm{yr}$ and $6 \mathrm{mmol} / \mathrm{m}^{2} / \mathrm{r}_{1} \mathrm{a}_{1}-1$. he associated values of $\mathrm{J}_{\max }$ are 20 $\mathrm{mmol} / \mathrm{m}^{2} / \mathrm{yr}$ and $40 \mathrm{mmol} / \mathrm{m}^{2} / \mathrm{yr}$, respectively (Table SI_6, In the two cases, the plant requirement is not satisfied and the active uptake obeys Michaelis-' 1 e. $t^{\text {ten }}$ kinetics. Hence, the value of the maximal influx will control the dynamics of boron and $\left.\mathrm{i}^{+}\right\lrcorner$is top ${ }^{2}$. A higher plant demand and thus a higher value of $J_{\max }$ results in an enhancement of the 'egetatı $n$ recycling and in a larger biomass pool of boron as well. At steady state, the stock of boror ir $\mathrm{c}_{\text {. }}$ living biomass is $8 \mu \mathrm{mol} / \mathrm{m}^{2}$ (about $90 \mathrm{mg} / \mathrm{m}^{2}$ ) when the Dem and $J_{\max }$ values are equal to $3 \mathrm{~m}_{1} \cdot \mathrm{ol} / \mathrm{m}^{2} / \mathrm{yr}$ and $20 \mathrm{mmol} / \mathrm{m}^{2} / \mathrm{yr}$, respectively, whereas it reaches 23 $\mu \mathrm{mol} / \mathrm{m}^{2}$ (about $250 \mathrm{mg} / \mathrm{m}^{2}$ ) for . Dem value equal to $6 \mathrm{mmol} / \mathrm{m}^{2} / \mathrm{yr}$ and a $\mathrm{J}_{\max }$ value equal to 40 $\mathrm{mmol} / \mathrm{m}^{2} / \mathrm{yr}$. Hence, $\mathrm{hi}_{\llcorner}{ }^{h} \mathrm{p}$ nt lemand increases the transient storage of ${ }^{10} \mathrm{~B}$ in the biomass and delays the return to steady-stat of the system. For instance, given a demand of $6 \mathrm{mmol} / \mathrm{m}^{2} / \mathrm{yr}$ and maximal influx of $40 \mathrm{mmol} / \mathrm{m}^{2} / \mathrm{yr}$, an enrichment in ${ }^{11} \mathrm{~B}$ of the soil solutions relative to the inputs lasting for about 1000 years is predicted by the model propagated to other B pools of the ecosystem (Figure $5 \mathrm{a}$ ). In the case where the active uptake of boron by roots does not fractionate $B$ isotopes, $\delta^{11} B$ values higher than $35 \%$ are predicted for soil solution within the root zone. This enrichment in the heavy isotope is even more marked for the leaf exudate characterized by isotopic compositions reaching $45 \%$ (Figure 5b) whereas the composition of the total inputs is about $18 \%$. 
Figure 5: Evolution with time of the B isotopic compositions of (a) the soil solutions and (b) living biomass as well as the leaf exudate for a B limited ecosystem characterized by different values of the plant demand and maximum B influx.

These high values for the soil pore water and leaf exudate are in line with the range of the isotopic compositions from $28 \%$ to $44 \%$ measured in the dissolved loa' of some tropical large rivers (Lemarchand et al., 2002; Louvat et al., 2011; Louvat et al., 2014). Bo: 7 th fluxes of boron at the base of the SOL and associated to leaf exudation are much larger thar $t_{1}, i^{\prime}$, puts by chemical weathering and atmospheric deposition (Figure SI_8). Hence, the high isotc: ic cc mpositions of these tropical large rivers could be explained by the control of overland flow of $\mathrm{cr}$ ᄅ riverine dissolved boron budget. This would imply that boron and along with other nutr.e +1 lost from the ecosystem, aggravating its boron deficiency. If so, boron isotopes reveal to he a gou -1 probe of the nutrient dynamic in ecosystems.

\subsection{Consequences of the loss of snii गrga.ıic boron by physical erosion in forest mountain ecosystems}

Removal of soil organic nutrient $\mathrm{L}$ : priysical erosion can exert an important control on nutrient cycling. For instance, Hilton et ㄱ. 201. ) highlighted the role of physical erosion on the loss of nitrogen from forest mountain ecosystem evidenced by the relationship between the $\mathrm{N}$ isotopic composition of soil organic matter and the slope of the catchment.

We conducted a same series of simulations for ecosystems where the plant demand for boron is fixed but which are characterized by different supply rates of boron and various loss rates of soil organic boron. In the simulations, the export rate, $\mathrm{k}_{\text {loss }}$, varies from $0.01 \mathrm{yr}^{-1}$ to $0.05 \mathrm{yr}^{-1}$ (Supporting Information SI_1, Table SI_7). In other way, between $1 \%$ and $5 \%$ of the soil organic boron stock is lost annually by physical erosion. 
A comparison of the temporal evolutions of B isotopic compositions of the different compartments of the ecosystem in the absence or not of erosion is illustrated in Figure 6.

Figure 6: Comparison of the temporal evolutions of B isotopic compositions for different supply rates of boron of the different compartments of the ecosystem in the absence (dashed curves) or not (full curves) of erosion. The upper panels show the evolutions of the isotopic compositions of the soil solutions and the lower panels the evolutions of the isotopic compositions of the living biomass and the leaf exudates.

Because the biomass is enriched in the light isotope, the remov $y$ of soil organic boron by soil erosion leads to a further increase of the B isotopic composition of the suil solutions relative to the inputs and consequently of the compositions of the different crmbartments of the ecosystem. The system will eventually reach a steady state but for which the i. ttopic compositions of boron leaving the root zone will be fractionated relative to the inputs and $\epsilon$. riched in the heavy isotope. For all the simulations, we assumed an absence of isotopic fraction : inn ?ssociated to the active uptake of boron by roots. In the case where the active uptake woulc fav $r$ the light isotope, enrichment in the heavy isotopes of the different pools would be enhanc. .

At steady-state, as the effi .len $y$ of the B cycling by the vegetation increases with the decrease of the boron supply rate, for a giv $n$ export rate, the ratio between the export of soil organic boron and the inputs increases with the decrease of B supply rates (Figure SI_9a). In addition, increase of the loss of soil organic boron might shift the status of an ecosystem from B non-limited to B limited (Figure SI_9a). When the system has reached a steady-state, for a given loss rate of organic boron by physical erosion, the magnitude of the shift of the $\delta^{11} \mathrm{~B}$ values compared with the composition of the inputs depends on the B status of the ecosystem. For B limited ecosystem, the model predicts enrichment in the heavy isotope of the SOL and SML dissolved boron between $12 \%$ and $19 \%$ for soil organic boron erosion rates 
of $19 \mu \mathrm{mol} / \mathrm{m}^{2} / \mathrm{yr}\left(200 \mu \mathrm{g} / \mathrm{m}^{2} / \mathrm{yr}\right)$ and $130 \mu \mathrm{mol} / \mathrm{m}^{2} / \mathrm{yr}\left(1,400 \mu \mathrm{gB} / \mathrm{m}^{2} / \mathrm{yr}\right)$ (Figures $8 \mathrm{~b}$ and $8 \mathrm{c}$ ). When boron is not limiting, this shift varies from less than $1 \%$ to nearly $12 \%$ for organic $B$ losses between 53 $\mu \mathrm{mol} / \mathrm{m}^{2} / \mathrm{yr}\left(570 \mu \mathrm{gB} / \mathrm{m}^{2} / \mathrm{yr}\right)$ and $150 \mu \mathrm{mol} / \mathrm{m}^{2} / \mathrm{yr}\left(1,620 \mu \mathrm{gB} / \mathrm{m}^{2} / \mathrm{yr}\right)$ (Figures SI_9b and SI_9c).

Similar evolution trends are predicted for the living biomass with enrichment in the heavy isotope compared with the values predicted in the absence of erosion between $15 \%$ and $20 \%$ o for strongly $B$ limited ecosystems (not shown).

For comparison, Hilton (2017) compiled the biospheric organic carbon xport rates by physical erosion from worldwide forested mountain catchments with values ranging fro n $1 \mathrm{gC} / \mathrm{m}^{2} / \mathrm{yr}$ to $87 \mathrm{gC} / \mathrm{m}^{2} / \mathrm{yr}$. Assuming that soil organic matter contains 50\% carbon in mass ( $\therefore$. $y l, 2010)$ and that its B content is around $10 \mathrm{ppm}$, similar to the value measured in litter (Fir. 'er, 1998), between $20 \mu \mathrm{g} / \mathrm{m}^{2} / \mathrm{yr}$ and about $1,750 \mu \mathrm{g} / \mathrm{m}^{2} / \mathrm{yr}$ of soil organic boron would be expor ier. hy physical erosion, in the range of the values predicted by the model.

\subsection{Responses of boron cycling to natu al a $-i$ anthropogenic disturbances}

In another series of simulation;, we explored the effects of forest disturbances (natural or anthropogenic) on the boron dyna nic. We performed runs where the whole tree stand was replaced (wood/root and leaf $k$ ' $>$ 'ss) for different return times (time interval between two perturbations) between 50 years and $\_$J0 years (Tables SI_8 and SI_9). These two periods are assumed to be characteristic of return times for temperate heavily managed forests and for undisturbed evergreen tropical forests (Pugh et al., 2019). For each simulation, the model is run for $500 / 1000$ years to initialize the stocks and isotopic compositions of the different boron pools of the ecosystem.

Effects of successive tree stand replacements on the B dynamic are illustrated in Figure 7 for two ecosystems, analogous of a temperate ecosystem heavily managed (e.g. clear cut logging) and a tropical evergreen forest faced with perturbations characterized by different return times. 
Figure 7: Boron dynamic for non-perturbed $(a, b)$ and for highly perturbed $(c, d)$ forested ecosystems characterized by return times ( $\left.T_{\text {return }}\right)$ of 1000 years and 50 years. For the non-perturbed ecosystem, initial values have been set by running the model for 1000 years whereas for the highly perturbed, initial values have been set by running the model for 500 years. The different figures show the evolution with time of the stocks of boron in the living biomass and the soil organic matter ( $a$ and $c$ ) and the isotopic composition of dissolved boron in the soil solutions as well as of the leaf exudates in the case the active uptake of boron by roots does not fractionate B isotopes ( $b$ and $d$ ).

The years following the clearing of the tree stand show a rapid $d f$ illı, of the B soil pore water pool and the soil organic pool as boron in soil solution and in soil organı matter is not sustained by vegetation cycling which results in hydraulic loss of boron associated to -rganic matter decay. This trend lasts till the growth of a secondary forest limits the wate $k<f$ boron from the soil solution and partially replenishes the soil organic pool. Because of 'ne nineralization of the soil organic matter, the B isotopic compositions of the soil solutions decreasc during the first years following the deforestation till the regrowth of a secondary forest proms:?s i $h$, accumulation of ${ }^{10} \mathrm{~B}$ in the biomass.

As expected, the difference betwe. $n$ the return time and the time needed for the ecosystem to reach a steady state controls the B ctnci- - f f the different compartments and the dynamic of boron. When the return time is long enoug. (1.e. 1000 years), the stocks of boron in the biomass will recover from the perturbations and even exceed the stocks at the end of the initializing run. This can be explained by the decay of the soil organic boron pool accumulated during the initializing run which became an additional source of boron. Not surprisingly, for heavily managed ecosystems with short return times (i.e. 50years), the system does not have time to fully recover. However, in this case, although the initial soil organic boron pool will decay providing an additional source of boron, because of the short return time, this pool will continuously decrease to near a steady value. The other observation is that in all the 
simulations after several perturbations, the system will reach a pseudo steady state where after each perturbation, the system returns to the pre-perturbation conditions.

Schlesinger and Vengosh (2016) highlighted the role of human disturbances on the global boron biogeochemical cycle. In this perspective, natural and anthropogenic disturbances are major drivers of the structure and function of terrestrial ecosystems, modifying biotic and abiotic patterns and processes (Bowd et al., 2019). Clear cut logging, for example is associated, to a rapid decline of soil dissolved and organic boron till the growth of a secondary forest limits the hydra ic loss of boron from the soil solution and partially replenishes the soil organic pool.

This is in-line with the evolution of the soil biogenic silica r.00, -., loss of dissolved silica following deforestation and replacement of the original forest by $\operatorname{crc}, \mathrm{s}_{\mathrm{h}} \mathrm{s}$ been highlighted in the Scheldt basin (Struyf et al., 2010), illustrating the sensitivity of nutri $n^{+}$, nools and fluxes to land use changes and their impacts on ecosystems. The consequences of , $u c_{1}$ ess, 'e disturbances is to maintain to a certain degree, depending on the return time and the siz $\supset$ of the pools, the boron cycle out of steady state even if the forest has reached its 'maturity' (ie for $r$ 't $r_{1}$ : imes of 1000 years) sustaining high isotopic compositions of the soil pore water.

\section{Conclusions and persp -ives}

We developed a model to investigate the boron dynamic during the development of forested ecosystems and to explore how the B stocks and associated isotopic compositions of different compartments will evolve with time. The aim of model is to simulate the dynamic of boron and its isotopes on relatively short time-scales, especially we focused on the response of the dynamics of boron and its isotopes to different B supply rates, plant demands, soil erosion and natural or anthropogenic disturbances. 
The overall conclusion of the sensitivity analysis developed in this paper is that the isotopic signature of boron in the ecosystem is characterized by a transient storage of ${ }^{10} \mathrm{~B}$ in biomass during the growth of the biosphere which enriches the soil solution within the root zone in the heavy isotope. This increase of the B isotopic composition of the root zone soil solution is propagated to the different compartments of the ecosystem. Enrichment in ${ }^{11} \mathrm{~B}$ relative to the inputs as high as $15 \%$ - $20 \%$ o can be produced for the leaf pool and soil pore water pool. This transient enrichment can last between 100 years to more than 500 years. Magnitude and duration of the transient increase of the isotopi compositions of the different $B$ pools in the ecosystem appear to decrease with the increase of B sur.ly. Thus, for ecosystems not limited by the supply of B from chemical weathering, vegetai ior ,, cling will have probably a limited impact on the B isotopic compositions of the different, ool, which will be in turn driven by the composition of the inputs, mainly controlled in this c isf ry chemical weathering processes (dissolution of rock minerals and neoformation of clays an $\_$, de.! In stable tectonic settings, like tropical lowlands, chemical weathering is limited by the suf nly of frush minerals resulting in higher B limitation and more efficient vegetation recycling. Atmosph ri _, - puts constitute probably a significant supply of boron to these ecosystems thus relatively hi, r, $₹$ demand by vegetation and relatively high B isotopic composition of the inputs would be respnnsit; 2 for the enrichment in ${ }^{11} \mathrm{~B}$ of the soil solution and of the $\mathrm{B}$ flux associated to vegetati $n$ c clir s (e.g. leaf exudation). Hence, one output of this model is that the interconnection betweer $\cdot$ eathering regimes, B limitation and vegetation recycling can be potentially fingerprinted by boron isotopes.

After the system has eventually reached a steady state, significant variation with depth in the root zone of the soil pore water B isotopic compositions is only observable when the adsorption of boron by roots fractionates its isotopes, otherwise the isotopic composition of the soil pore water within the root zone tends to be homogenized by vegetation cycling and is controlled by the $\delta^{11} \mathrm{~B}$ value of the inputs. 
Loss of soil organic boron by physical erosion would also modify boron dynamic of ecosystems. Because of the more efficient B recycling by the vegetation for limited ecosystem, the loss of boron by soil erosion normalized to the total inputs by chemical weathering and atmospheric depositions is higher than for B non-limited ecosystems. Consequently, after the system has reached a steady state, the partial loss of this pool enriched in ${ }^{10} \mathrm{~B}$ results in variable enrichment in the heavy isotope relative to the values in the absence of erosion depending on the degree of B limitation. For B non-limited ecosystems, loss by erosion would probably have less impact on the B isotopic com nsition of the different pools of the ecosystem than for B limited ecosystems.

In spite of the uncertainties on some parameters, the model lev '. ped here can reproduce at a first order, the distribution of B and its isotopes in different $t$ - osv, tems Although the number of studies allowing a comparison is still limited, our work pro idr.s a conceptual framework necessary to guide future boron isotopic measurement in ecosyst $\_m$ pa. ning climatic or geological gradients. For instance, assessment of fluxes and pools of borc ${ }^{n}$ at ditı erent stages of forest development or for forested ecosystems developed on soil chronos $\mathrm{a} \lambda \mathrm{t}^{-2}=\mathrm{e}$ and hence characterized by different $\mathrm{B}$ supply rates, could be used to test the model's rr dictions and in return, refine it. Impacts of the loss of soil organic boron by erosion on boron Nyna, ic and export of organic boron would need to be quantified by studying ecosystems dt 'elı ned along slope gradient for example. developed in this paper is also simple and flexible and could be -apted to other nutrients. However, the main advantage of boron compared with other elements is the relatively large isotopic fractionation associated to vegetation cycling resulting in a large range of isotopic compositions across the different pools which allows to follow the $B$ dynamic at the scale of an ecosystem. Analysis of B isotopes in tree rings might potentially record the dynamic of B during the development of an ecosystem as well as the responses to different perturbations. In addition, recycling of silicon by vegetation has been proposed to sustain clays formation in upper soil horizon even for highly weathered soil profiles (Lucas et al., 1993). As shown 
here, vegetation recycling can also maintain relatively high dissolved B concentration in the upper soil, hence, co-precipitation with secondary minerals of boron from soil solution enriched in ${ }^{11} \mathrm{~B}$ by vegetation recycling could also potentially record the print of the 'biogenic' origin of these clay minerals.

\section{Acknowledgements}

BC was financially supported by the NNSFC (grants No 41473023, 415 11 ? 4017, U1612442) and JBC by the NNSFC (grants No 41625012, 41961144028 and 41830647) $>n+$ by the National Key Research and Development Program of China (2019YFC1804400). The codr _ re ' to generate the data is available at https://github.com/benjaminchetelat/Benjamin_Chetelat for . view and as stated will be archived in a public repository (Zenodo repository) in the case the $\mathrm{r}$ lar.uscript is accepted for publication. The authors declare no conflicts of interest.

\section{References}

Baes C.F. and Mesmer R.E. (19- j) The Hydrolysis of Cations. Wiley, New York.

Bolaños L., Lukaszewski K., Bonilla I. and Blevins D. (2004) Why boron? Plant Physiol. Biochem., 42, $907-912$

Bouchez J., von Blanckenburg F. and Schuessler J.A. (2013) Modeling novel stable isotope ratios in the weathering zone. American Journal of Science, 313, 267-308

Bowd E.J., Banks S.C., Strong C.L. and Lindenmayer D.B. (2019) Long-term impacts of wildfire and logging on forest soils. Nature Geoscience, 12, 113-118 
Buendia C., Kleidon A. and Porporato A. (2010) The role of tectonic uplift, climate, and vegetation in the long-term terrestrial phosphorous cycle. Biogeosciences, 7, 2025-2038

Camacho-Cristobal J.J., Rexach J. and Gonzalez-Fontes A. (2008) Boron in Plants: Deficiency and Toxicity. Journal of Integrative Plant Biology, 50, 1247-1255

Cividini D., Lemarchand D., Chabaux F., Boutin R. and Pierret M.C. (2010) From biological to lithological control of the B geochemical cycle in a forest watershed (Strengbach, Vosges). Geochimica et Cosmochimica Acta, 74, 3143-3163

Dannel F., Pfeffer H., Walch-Liu P. and Romheld V. (2001) Characteristics of $\mathrm{c}$ ron uptake in roots of sunflower by a putative boron transporter. In: Plant Nutrition: Food securitı a. N sustainability of agro-ecosystems through basic and applied research (eds. Horst WJ, Scherk, N, Burkert A, Claassen N, Flessa H, Frommer WB, Goldbach H, Olfs HW, Romheld V, Sattelmach $r$ s, : chmidhalter U, Schubert S, v. Wiren N and Wittenmayer L), pp. 162-163. Springer Ne .ner inds, Dordrecht

Ding T.P., Ma G.R., Shui M.X., Wan D.F. and Li R.ı : (2005) Silicon isotopes study on rice plants from the Zhejiang Province, China. Chem. Geol., 2184150

Finer L. (1989) Biomass and nutrien+ $\mathrm{cyc}^{\prime} \cdot \mathrm{s}$ in fertilized and unfertilized pine, mixed birch and pine and spruce stands on a drained m: - An ${ }^{+}$Forestalia Fennica, 208, 1-63

Gaillardet J. and Lemarchand D (2018) Boron in the Weathering Environment. In: Boron isotopes: the fifth element (eds. Marschall H and Foster GL), pp. 163-188. Springer

Galbraith D., Malhi Y., Affum-Baffoe K., Castanho A.D.A., Doughty C.E., Fisher R.A., Lewis S.L., Peh K.S.H., Phillips O.L., Quesada C.A., Sonke B. and Lloyd J. (2013) Residence times of woody biomass in tropical forests. Plant Ecology and Diversity, 6, 139-157

Geilert S., Vogl J., Rosner M., Voerkelius S. and Eichert T. (2015) Boron isotope fractionation in bell pepper. Mass Spectrometry and Purification Techniques, 1, 1-6 
Geilert S., Vogl J., Rosner M. and Eichert T. (2019) Boron isotope variability related to boron speciation (change during uptake and transport) in bell pepper plants and SI traceable $n\left({ }^{11} \mathrm{~B}\right) / n\left({ }^{10} \mathrm{~B}\right)$ ratios for plant reference materials. Rapid Communications in Mass Spectrometry, 33, 1137-1147

Hilton R.G. (2017) Climate regulates the erosional carbon export from the terrestrial biosphere. Geomorphology, $277,118-132$

Hilton R.G., Galy A., West A.J., Hovius N. and Roberts G.G. (2013) Geomorphic control on the $\delta^{15} \mathrm{~N}$ of mountain forests. Biogeosciences, 10, 1693-1705

Holmden C. and Belanger N. (2010) Ca isotope cycling in a forested ecos' steı. . Geochimica et Cosmochimica Acta, $74,995-1015$

Jobbagy E.G. and Jackson R.B. (2001) The distribution of soil nuti ,ents with depth: Global patterns and the imprint of plants. Biogeochemistry, 53, 51-77

John R., Dalling J.W., Harms K.E., Yavitt J.B., Stallard R.. $\quad$ Mirabello M., Hubbell S.P., Valencia R., Navarrete H., Vallejo M. and Foster R.B. (2007) So: . . , trı ints influence spatial distributions of tropical tree species. Proceedings of the National Aca terı.' of Sciences, 104, 864-869

Klochko K., Kaufman A.J., Yao W., Byrı - R.H. and Tossell J.A. (2006) Experimental measurement of boron isotope fractionation in soaw iter. :arth and Planetary Science Letters, 248, 276-285

Lehto T., Ruuhola T. and Delı ๖. (2010) Boron in forest trees and forest ecosystems. Forest Ecology and Management, 260, 2053-2069

Lemarchand D., Gaillardet J., Lewin E. and Allègre C.J. (2002) Boron isotope systematics in large rivers: implications for the marine boron budget and paleo-pH reconstruction over the Cenozoic. Chem. Geol., 190, 123-140

Lemarchand E., Schott J. and Gaillardet J. (2005) Boron isotopic fractionation related to boron sorption on humic acid and the structure of surface complexes formed. Geochim. Cosmochim. Acta, 69, 3519-3533 
Lloyd J. and Taylor J.A. (1994) On the temperature dependence of soil respiration. Functional ecology, 83, 315-323

Louvat P., Gaillardet J., Paris G. and Dessert C. (2011) Boron isotope ratios of surface waters in Guadeloupe, Lesser Antilles. Applied Geochemistry, 26, S76-S79

Louvat P., Gayer E. and Gaillardet J. (2014) Boron behavior in the rivers of Réunion island inferred from boron isotope ratios and concentrations of major and trace elements. Procedia Earth and Planetary Science, 10, 231-237

Lucas Y., Luizaõ F.J., Chauvel A., Rouiller J. and Nahon D. (1993) The relation beiv sen biological activity of the rain forest and mineral composition of soils. Science, $260,521-523$

Marentes E., Vanderpool R.A. and Shelp B.J. (1997) Boron-isotope fracı. ?nation in plants. Canadian Journal of Plant Science, 77, 627-629

O'Neil M.A. (2001) Boron, Pectins, and Plant Cell Walls. s, ienı $=, 294,741$

Park H. and Schlesinger W.H. (2002) Global biogeocht. nical cycle of boron. Global Biogeochem. Cycles, 16, 1-11

Pfeffer H., Dannel F. and RÖmheld V. (1998) $\mathrm{A} \mathrm{r} \leq \mathrm{t}$. . re connections between phenol metabolism, ascorbate

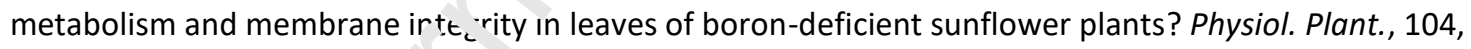
$479-485$

Pietsch K.A., Ogle K., Cornt. 'st. I' ' '.C., Cornwell W.K., Bonisch G., Craine J.M., Jackson B.G., Kattge J., Peltzer D.A., Penuelas J., Reich F.z., Wardle D.A., Weedon J.T., Wright I.J., Zanne A.E. and Wirth C. (2014) Global relationship of wood and leaf litter decomposability: the role of functional traits within and across plant organs. Global Ecology and Biogeography, 23, 1046-1057

Porporato A., D'Odorico P., Laio F. and Rodriguez-Iturbe I. (2003) Hydrologic controls on soil carbon and nitrogen cycles. I. Modeling scheme. Advances in Water Resources, 26, 45-58

Pribyl D.W. (2010) A critical review of the conventional SOC to SOM conversion factor. Geoderma, 156, 75-83 
Pugh T.A.M., Arneth A., Kautz M., Poulter B. and Smith B. (2019) Important role of forest disturbances in the global biomass turnover and carbon sinks. Nature Geoscience, 12, 730-735

Riotte J., Meunier J.-D., Zambardi T., Audry S., Barboni D., Anupama K., Prasad S., Chmeleff J., Poitrasson F., Sekhar M. and Braun J.-J. (2018) Processes controlling silicon isotopic fractionation in a forested tropical watershed: Mule Hole Critical Zone Observatory (Southern India). Geochimica et Cosmochimica Acta, 228, 301-319

Roux P., Turpault M.-P., Kirchen, G. Redon P.-O. and Lemarchand D. (2017) Boruı. dissolved and particulate atmospheric inputs to a forest ecosystem (Northeastern France). Fn. irnr. Sci. Technol., 54 14038-14046

Schlesinger W.H and Jasechko S. (2014) Transpiration in the global watt · cycle. Agricultural and Forest Meteorology,189-190,115-117

Schlesinger W.H. and Vengosh A. (2016) Global boron cy- e irı :ie Anthropocene. Global Biogeochem. Cycles, 30, 112

Silberbush M., Ben-Asher J. and Ephrath J.E. ( $<$ ר) $\therefore$ model for nutrient and water flow and their uptake by plants grown in a soilless culture. Plani anı.' Soil, 271, 309-319

Stangoulis J.C.R., Reid R.J., Brown P.H. nd Graham R.D. (2001) Kinetic analysis of boron transport in Chara. Planta, $213,142-146$

Stangoulis J., Tate M., Grahaı R., Bucknall M., Palmer L., Boughton B. and Reid R. (2010) The mechanism of boron mobility in wheat and canola phloem. Whole Plant and Ecophysiology, 153, 876-881

Steidinger B. (2015) Qualitative differences in tree species distributions along soil chemical gradients give clues to the mechanisms of specialization: why boron may be the most important soil nutrient at Barro Colorado Island. New Phytologist, 206, 895-899 
Struyf E., Smis A., Van Damme S., Garnier J., Govers G., Van Wesemael B., Conley D.J., Batelaan O., Frot E., Clymans W., Vandevenne F., Lancelot C., Goos P. and Meire P. (2010) Historical land use change has lowered terrestrial silica mobilization. Nature Communications, 1, 129

Turner B.L., Zalamea P.-C., Condit R., Winter K., Wright S.J. and Dalling J.W. (2017) No evidence that boron influences tree species distributions in lowland tropical forests of Panama. New Phytologist, 214, 108-119

Warington K (1923). The effect of boric acid and borax on the broad bean and certain other plants. Ann. Bot. 37, $629-672$

Xue B.-L., Guo Q., Hu T., Xiao J., Yang Y., Wang G., Tao S., Su Y., Liu J. and Zha. X. (2017) Global patterns of woody residence time and its influence on model simulation of abnve round biomass. Global Biogeochemical Cycles, 31, 821-835

Yamagishi M. and Yamamoto Y. (1994) Effects of boron c. nou ${ }^{2}$ le development and symbiotic nitrogen fixation in

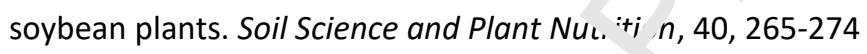

Figure 1: Schematic description of the model with the different pools and fluxes considered. A list and a description of the pools, fluxes, and parameters are given Tables SI 1 and SI 2 


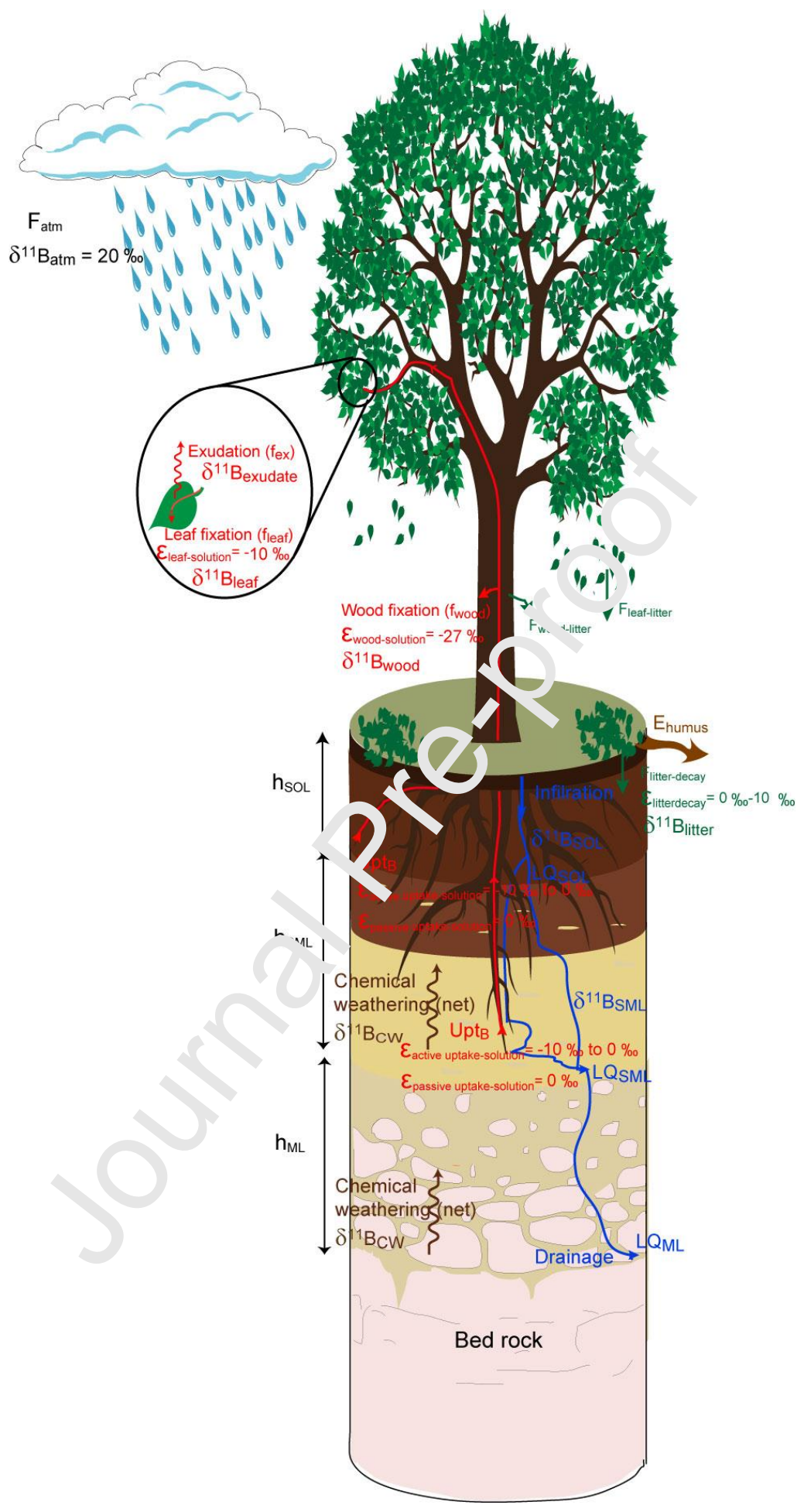

Figure 2: Evolution of the $B$ isotopic composition of the soil solution in 3 different soil layers with the development of a forest for different supply rates of boron (atmospheric inputs, $F_{\text {atm }}$ and chemical weathering, CW) and different $B$ fractionation factors associated $(\varepsilon)$ to the active uptake of boron by roots 


\section{Journal Pre-proof}

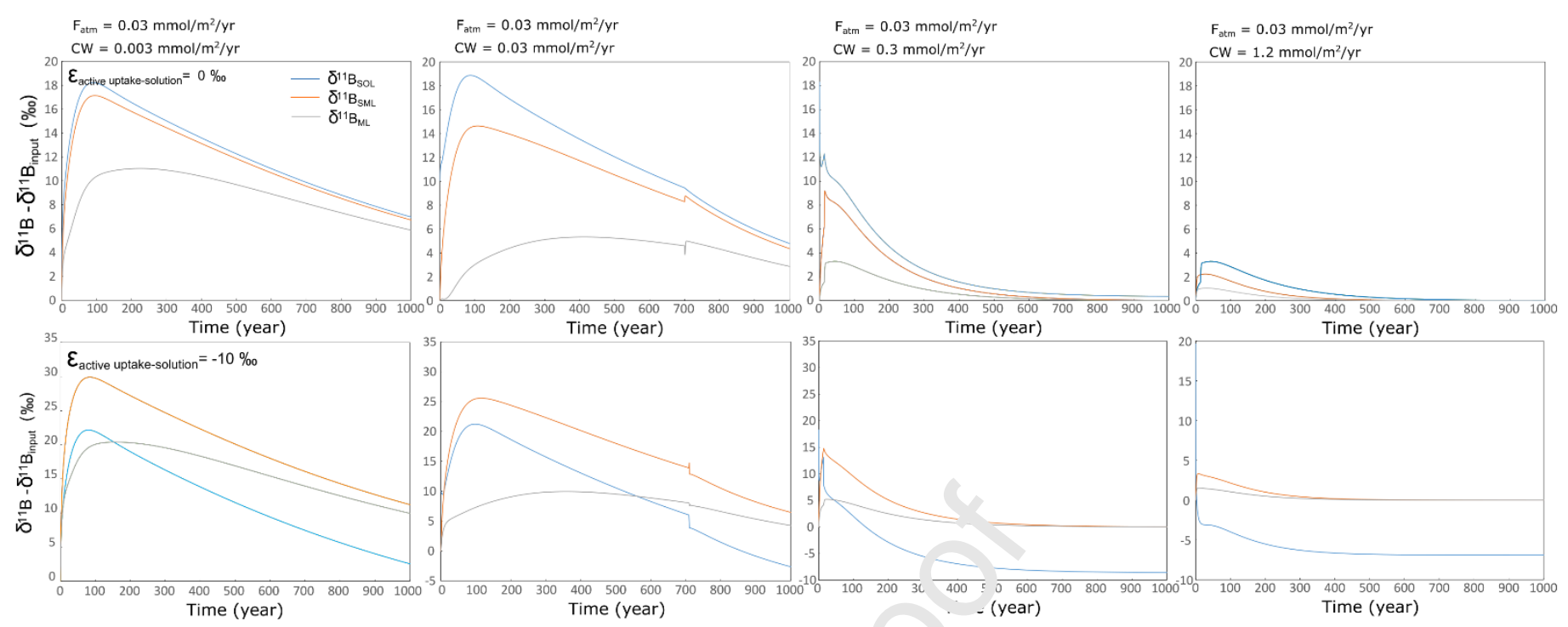

Figure 3: Evolution of the $B$ isotopic compositions of the living biomass and the leaf exudate with the development of a forest for different supply rates of boron (atmospheric inputs, $F_{\text {atm }}$ and chemical 


\section{Journal Pre-proof}

weathering, CW) and different B fractionation factors $(\varepsilon)$ associated to the active uptake of boron by roots
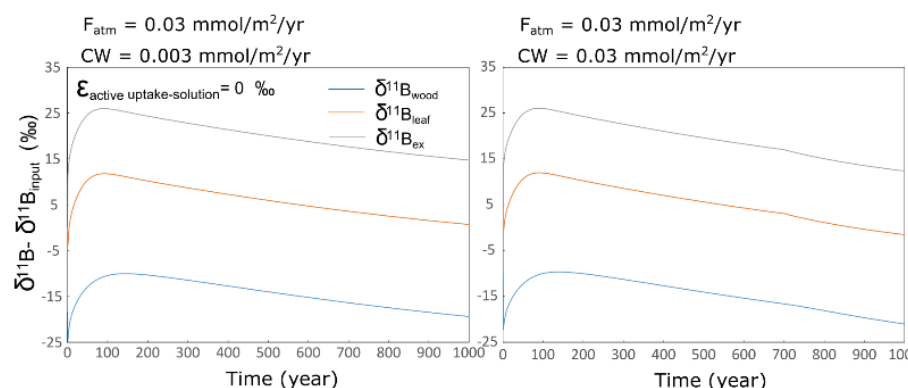

$F_{\text {atm }}=0.03 \mathrm{mmol} / \mathrm{m}^{2} / \mathrm{yr}$ $\mathrm{CW}=0.3 \mathrm{mmol} / \mathrm{m}^{2} / \mathrm{yr}$ $F_{\text {atm }}=0.03 \mathrm{mmol} / \mathrm{m}^{2} / \mathrm{yr}$ 30 $\mathrm{CW}=0.3 \mathrm{mmol} / \mathrm{m}^{2} / \mathrm{yr}$
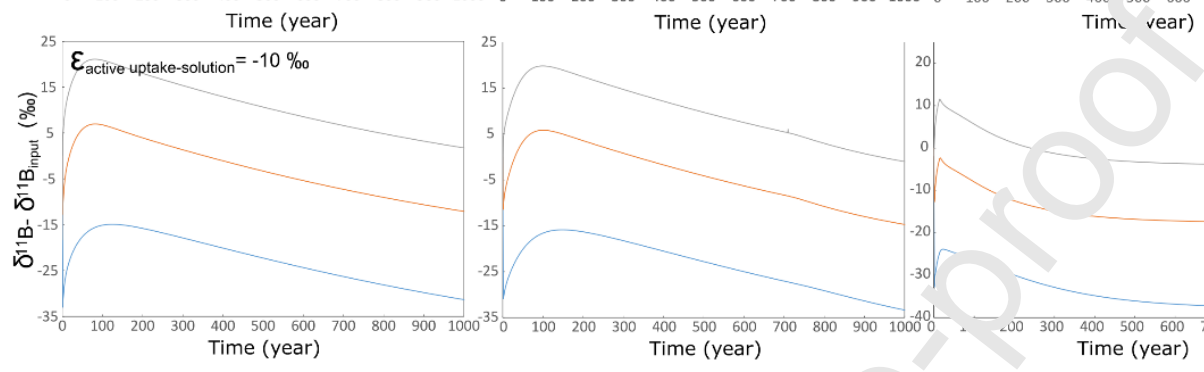
$400 \quad 500 \quad 600$
Time (year) $\mathrm{CW}=1.2 \mathrm{mmol} / \mathrm{m}^{2} / \mathrm{yr}$ Time (year)
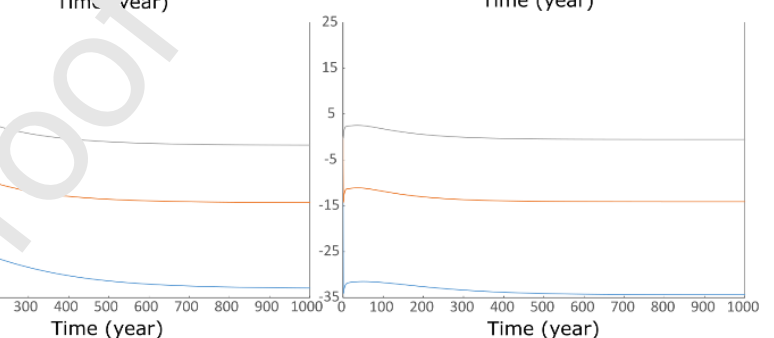
Figure 4: Relationships at steady state between the demand normalized to the inputs and (a) the vegetation cycling, (b) the ratio between the active uptake and the passive uptake of boron by roots, (c) and (d) the enrichment in B of the organic soil layer and the bottom layer of the root zone. The limit for boron limitation has been fixed arbitrarily and marks the transition between the two formulations for active $B$ uptake by roots (see text for details)
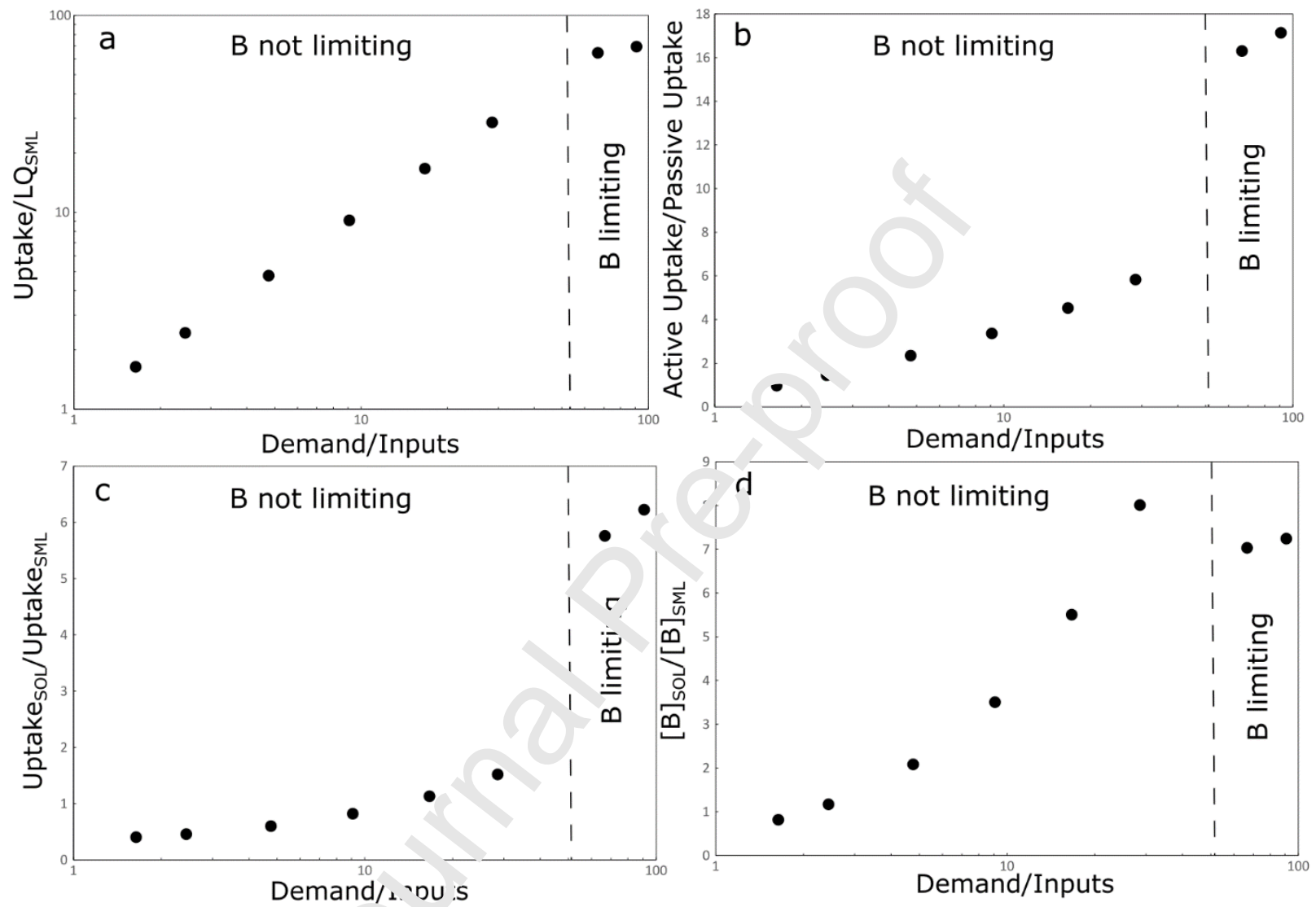
Figure 5: Evolution with time of the B isotopic compositions of (a) the soil solutions and (b) living biomass as well as the leaf exudate for a $B$ limited ecosystem characterized by different values of the plant demand and maximum $B$ influx.
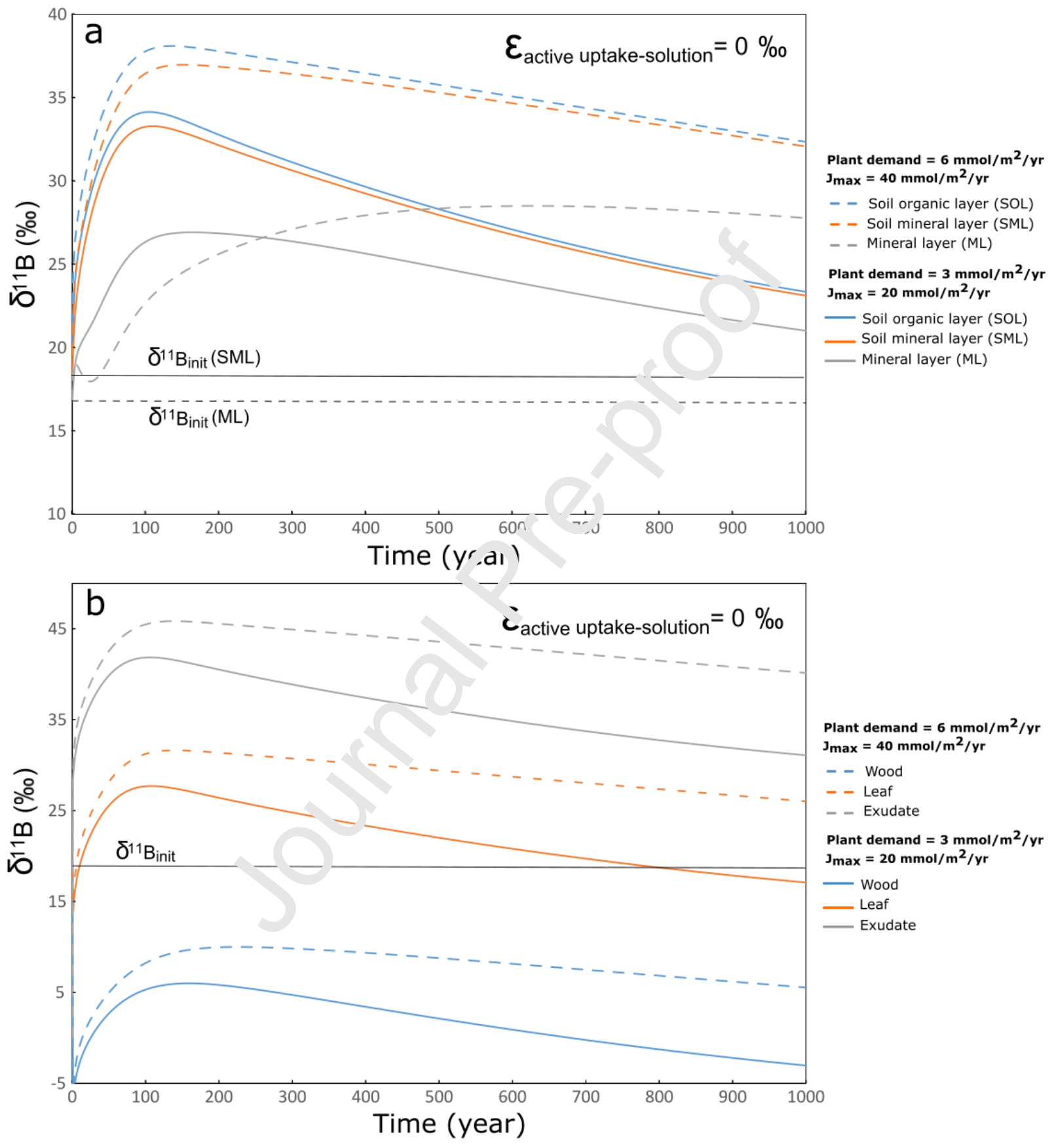


\section{Journal Pre-proof}

Figure 6: Comparison of the temporal evolutions of B isotopic compositions for different supply rates of boron of the different compartments of the ecosystem in the absence (dashed curves) or not (full curves) of erosion. The upper panels show the evolutions of the isotopic compositions of the soil solutions and the lower panels the evolutions of the isotopic compositions of the living biomass and the leaf exudates.
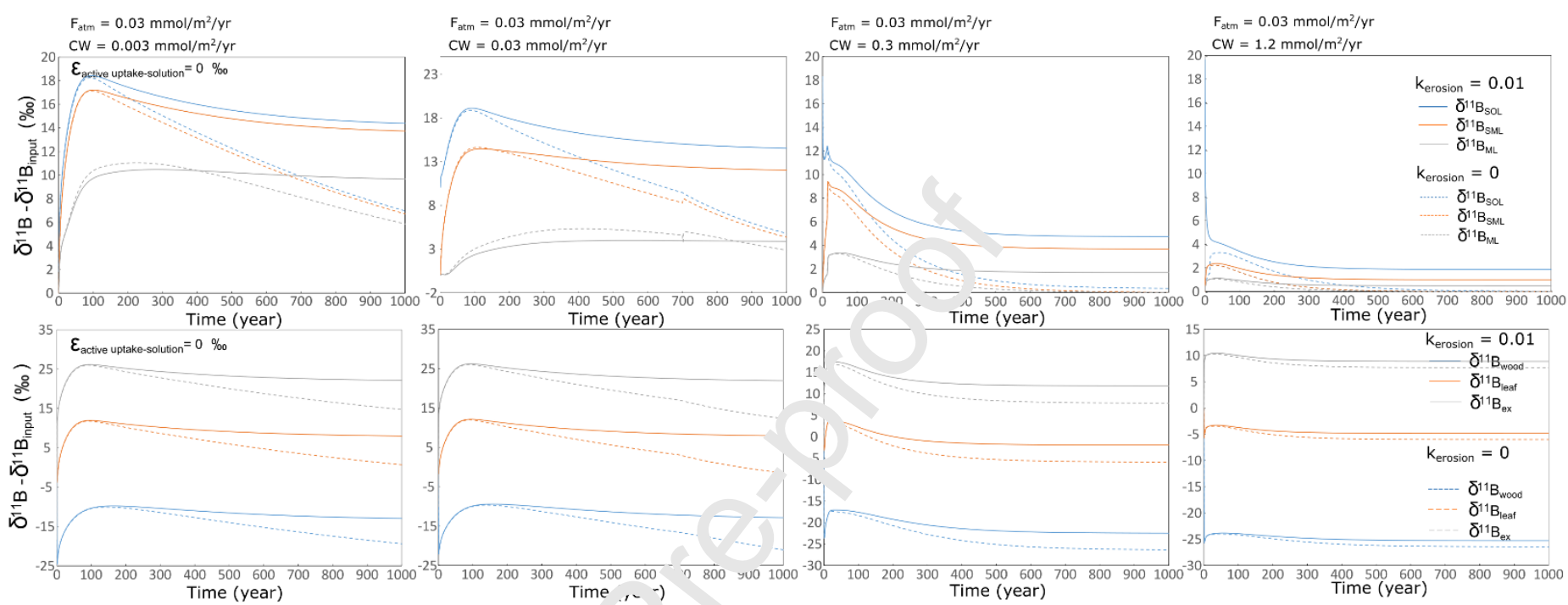
Figure 7: Boron dynamic for non-perturbed $(a, b)$ and for highly perturbed $(c, d)$ forested ecosystems characterized by return times $\left(T_{\text {return }}\right)$ of 1000 years and 50 years. For the non-perturbed ecosystem, initial values have been set by running the model for 1000 years whereas for the highly perturbed, initial values have been set by running the model for 500 years. The different figures show the evolution with time of the stocks of boron in the living biomass and the soil organic matter (a and c) and the isotopic composition of dissolved boron in the soil solutions as well as of the leaf exudates in the case the active uptake of boron by roots does not fractionate $B$ isotopes ( $b$ and $d$ ).
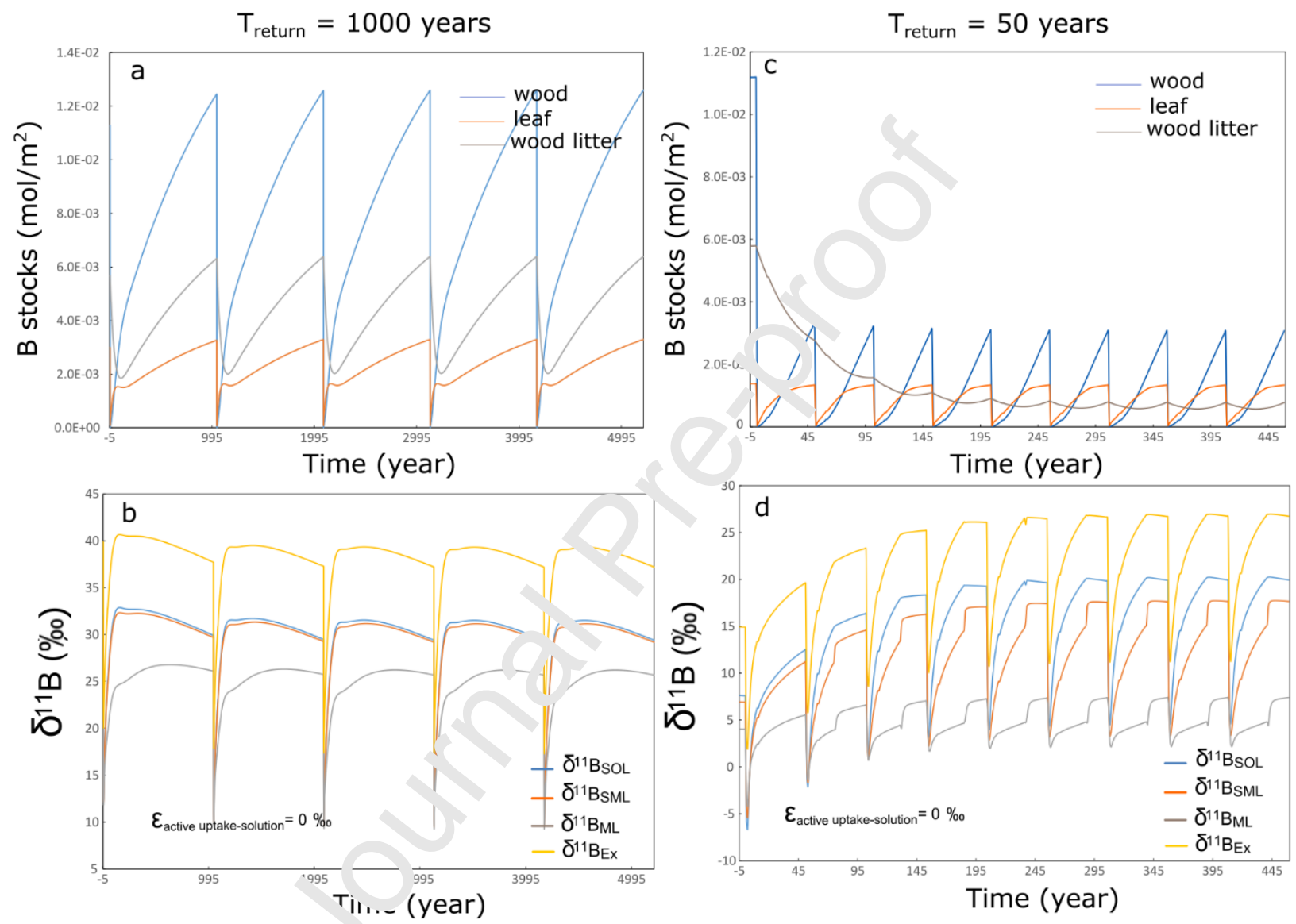
Declaration of interest

The authors declare no conflicts of interest. 